\title{
Relation between Running Time and Energy Consumption
}

J. Opava*

Czech Technical University in Prague, Faculty of Transportation Sciences, Department of Economics and Management, Czech Republic

*Corresponding author: opava@fd.cvut.cz

\begin{abstract}
The traditional solution of energy efficiency has, up to now, lain in research into the design of electric traction equipment and utilizing the latest findings in electric materials, semi-conductors, driving and regulating aggregates and production technologies. Economical and ecological requirements create impulses for searching for different routes leading to the energy efficiency of electric railway operation, just like in other fields of technology. Research in this field has embarked on searching for unconventional options, characterized by the examination of the relationship between running time and energy consumption. This approach defines a rational method of the train guiding and can deduce ideal requirements for creating timetables. This paper elaborates on a particular approach to a given problem and introduces achieved outcomes.
\end{abstract}

KEY WORDS: Electric railway, running time, energy consumption, energy saving, energy navigation instrument.

\section{INTRODUCTION}

The examination of relations between running time and appropriate energy consumption on a given track serves as a ground for energy optimizing of the timetable. It is clear that optimal running time does not only concern energy, but also technological, commercial and other factors. The following contemplations, however, involve only the energy aspects; they need not necessarily satisfy other factors, which are not subject of this work. In an attempt to capture the relations between energy consumption, track gradient, speed (i.e. running time) in the most comprehensive form, an extensive analytical study, based on variant calculations, has been performed and documented by measurements in real train operations. A 363 Series locomotive, which is used on Czech railways, was used as the traction vehicle. Relevant tractive effort - speed and power input - speed functional relations were elaborated on the original data in the manufacturing documentation of the Company Elektrické lokomotivy, ŠKODA Plzeň, and on the author's work team's own measurements.

\section{THEORETICAL BACKGROUND}

The most accurate results for calculating power consumption are achieved by an integrative method, which is described in the following mathematical relations. The calculation is simulating; this means that it simulates the particular passage of a train 
under given operational technological conditions. For instantaneous acceleration the following applies:

$$
\frac{d V}{d t}=\frac{f_{t}\left(V, \tau_{x}\right)-\left[r_{v}(V)+r_{g}+r_{c}\right]}{102 . \xi} \quad\left[\mathrm{m} / \mathrm{s}^{2}\right]
$$

where the relative tractive effort on the driving wheels' perimeter is characterized by:

$$
f_{t}\left(V, \tau_{x}\right)=\frac{102 F_{t}\left(V, \tau_{x}\right)}{M} \quad[\mathrm{~N} / \mathrm{kN}, \mathrm{kN}, \mathrm{t}]
$$

Then, if we consider that in the real time interval

$$
\Delta t=t_{2}-t_{1}
$$

it is possible to simplify relation (2) for the selected function $\tau_{x}(V)$ and regard it as the function of the speed, i.e.

$$
f_{t}\left(V, \tau_{x}\right)=f_{t}(V)
$$

The time function relation of the speed for $t \in\left\langle t_{1}, t_{2}\right\rangle$ is then determined by the Formula

$$
V(t)=\frac{3,53 \cdot 10^{-2}}{\xi} \int_{t_{1}}^{t_{2}}\left\{f_{t}(V)-\left[r_{v}(V)+r_{g}+r_{c}\right]\right\} d t \quad[\mathrm{~km} / \mathrm{h}]
$$

Then, the corresponding time function of power input on the locomotive current collector is

$$
P_{1 t}(t)=\frac{F_{t}[V(t)] \cdot V(t)}{3,6 \eta_{T V E}\left\{F_{t}[V(t)], V(t)\right\}} \quad[\mathrm{kW}, \mathrm{kN}, \mathrm{km} / \mathrm{h}, 1]
$$

and the energy consumed on the the locomotive input in the contemplated time interval (3) is

$$
E_{1}(t)=\frac{1}{3600} \int_{t_{1}}^{t_{2}} P_{1 t}(t) \cdot d t
$$

\section{Symbols used in the above mentioned equations:}

$\begin{array}{ll}\mathrm{V} & \text { speed }[\mathrm{km} / \mathrm{h}] \\ F_{t} & \text { tractive effort on the perimeter of driving wheels }[\mathrm{kN}] \\ f_{t} & \text { relative tractive effort on the driving wheels }[\mathrm{N} / \mathrm{kN}] \\ \tau_{x} & \text { fictive regulation driving position - corresponds with particular tractive effort } \\ \xi & \text { speed functional relation } \\ \xi & \text { coefficient of rotational mass influence }[1] \\ r_{v} & \text { relative vehicle resistance }[\mathrm{N} / \mathrm{kN}] \\ r_{g} & \text { relative grade resistance }[\mathrm{N} / \mathrm{kN}] \\ r_{c} & \text { relative resistance during passage through a track curve }[\mathrm{N} / \mathrm{kN}] \\ \eta_{T V E} & \text { instantaneous total energy efficiency of the locomotive }[1]\end{array}$


The necessity to apply accurate calculations achieved by means of the above-described integrative method, which corresponds with the correct instanteneous value of the overall efficiency of the traction vehicle $\eta_{T V E}$, is obvious in Figure 1. It is obvious that the value of energy efficiency of an electric traction vehicle largely depends on the tractive effort on the driving wheels $F_{t}$ and on the speed $V$.

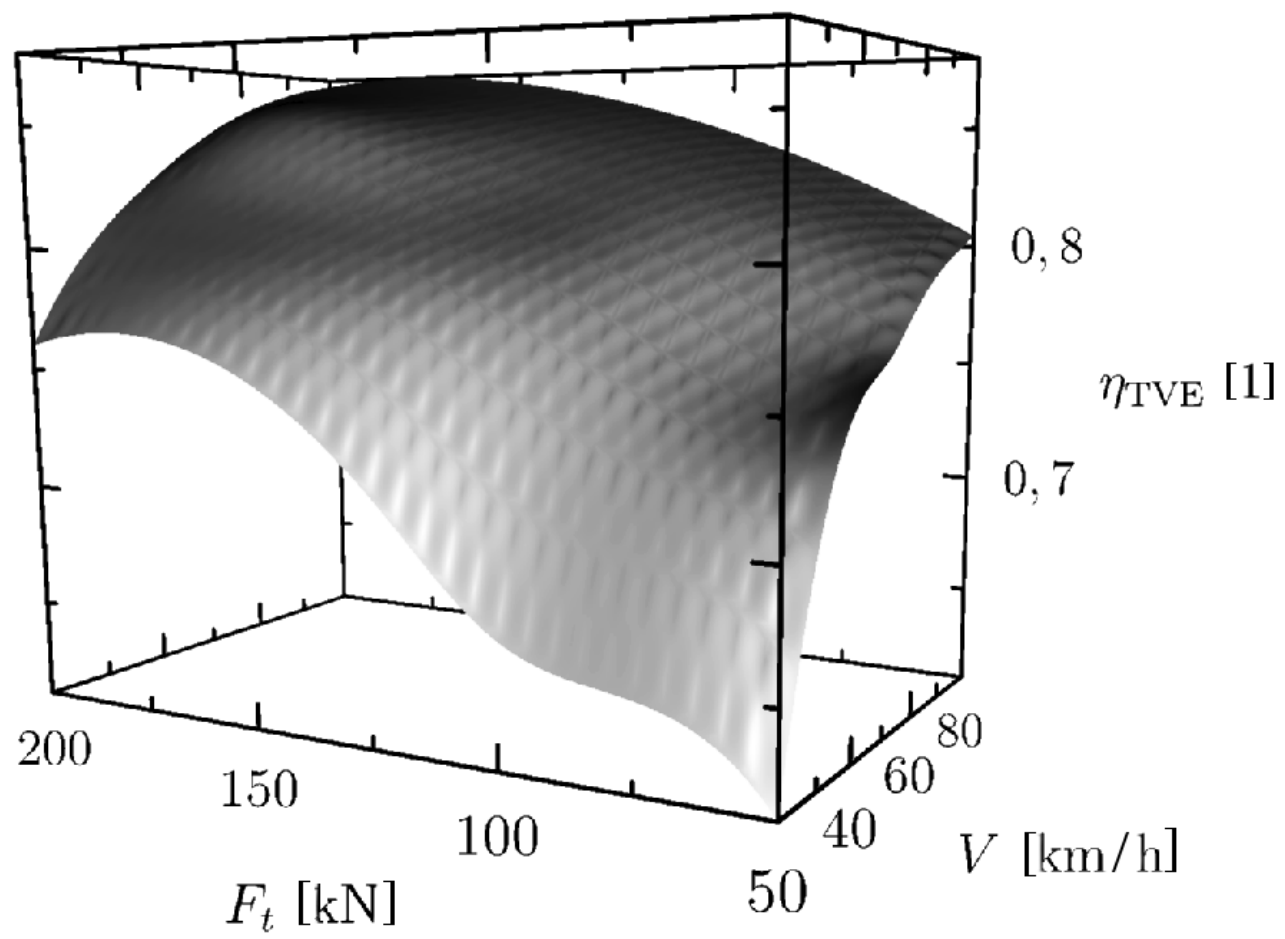

Figure 1: Values of the overall efficiency $\eta_{T V E}$ for various power modes determined by the tractive effort on the driving wheels $F_{t}$ and the speed $V$

\section{RESEARCH METHOD}

Figure 2 gives a graphic description of the dependence of relative energy consumption measured on the current collector $e$ on vehicle velocity $V$ for two types of train, which differ in vehicle resistance and total mass $M$. The influence of gradient $g$ was also taken into account.

The results of this are the so-called V-curves, which provide a graphic description of the general relation between relative energy consumption $e$ at a constant speed $V$ and a given track gradient $g$. If we selected minimum power consumption as the optimization criterion, the optimum would become the local minimum of each displayed function corresponding to the particular velocity, in this case between $38 \mathrm{~km} / \mathrm{h}$ (curve 1) and $53 \mathrm{~km} / \mathrm{h}$ (curve 5). This fact suggests that the energetic optimum cannot be determined by the local minimum of individual functions $e(V, g, M)$, due to practical traffic and technological reasons.

The relevant speeds are unacceptably low. Thus it is necessary to look for a different approach to power optimization criterion. 


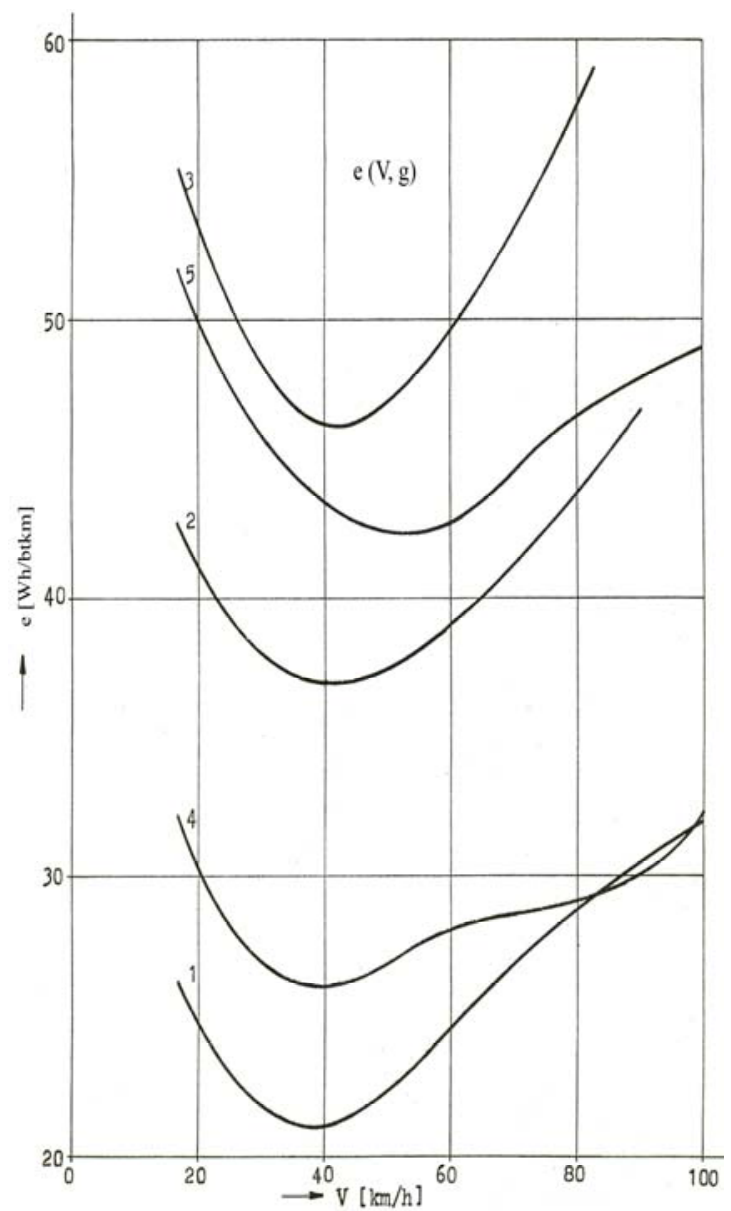

Comment on Figure 2:

\section{Curve 1}

Goods train - total mass $890 t$ on the gradient $4 \%$

\section{Curve 2}

Identical train on the gradient $8 \%$

\section{Curve 3}

Identical train on the gradient $12 \%$

\section{Curve 4}

Express train - total mass $420 t$ on the gradient $5 \%$

\section{Curve 5}

Identical train on the gradient

Figure 2: Relation between relative energy consumption on the locomotive's current collector $e$ and speed $V$, mass of train $M$ and track gradient $g$ for two different types of train

A study based on variant calculations, which examined the relations between energy consumption, gradient and running time by simulating a complete running cycle between two stops in the most universal conception.

Calculations were performed with software equipment which was created by the work team under the author's guidance by utilizing his previous research activities in these model conditions:

- express train - total mass $420 \mathrm{t}$,

- maximum speed $-100 \mathrm{~km} / \mathrm{h}$,

- distance between two stops - $30 \mathrm{~km}$,

- constant gradient whose values are in intervals from -16 to $+16 \%$. 
Graphical summery of outcomes of the studies the Figure 3.

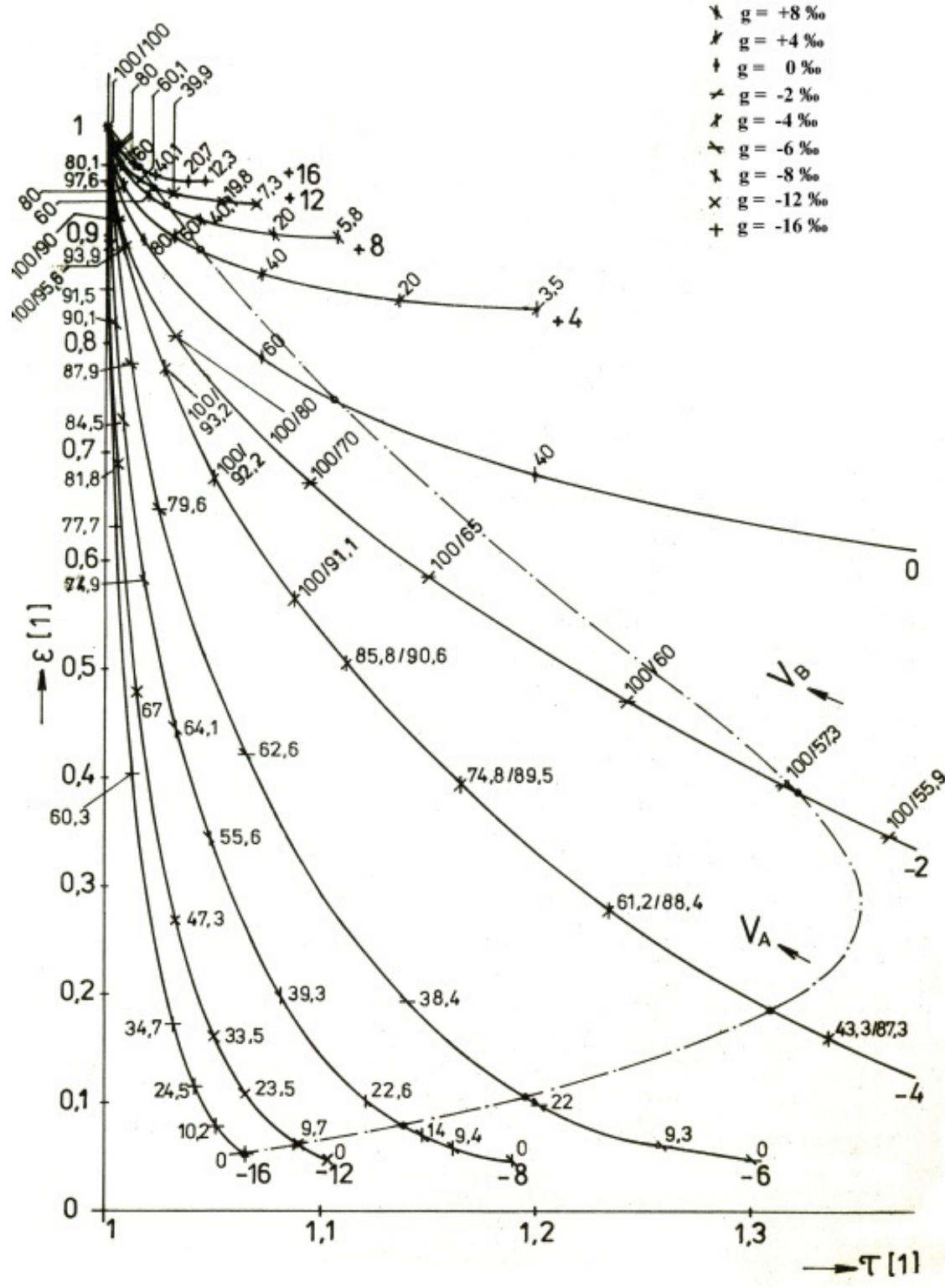

Figure 3: Relationship between energy consumption $\varepsilon$ and running time $\tau$ at various gradients $g$ in simulation of a complete driving cycle

\section{Comment on Figure 3:}

Curves $\varepsilon(\tau)$ for gradient $-2 \%$ are marked with points and specified by fractions, where the numerator represents the speed at the beginning of the coasting and the denominator represents the speed at the beginning of braking before stopping. Speed at the beginning of the coasting is consolidated at $100 \mathrm{~km} / \mathrm{h}$. For other curves for gradients up to $+16 \%$, the particular points are only marked with data on the speed reached at the beginning of braking $\left(\mathrm{V}_{\mathrm{B}}\right)$. On curves $\varepsilon(\tau)$ for gradient $-4 \%$, the points are specified by speed at the end of the driving with power in the numerator and speed at the beginning of braking in the denominator. Other curves for gradients up to $-16 \%$ are only marked with speed at the end of the driving with power $\left(\mathrm{V}_{\mathrm{A}}\right)$. 
For the formulation of energy consumption, this holds true:

$$
\varepsilon=\frac{E}{E_{\max }} \quad[1, \mathrm{kWh}, \mathrm{kWh}]
$$

For the formulation of running time, this holds true:

$$
\tau=\frac{T}{T_{\min }} \quad[1, \min , \min ]
$$

where $\mathrm{E}_{\max }$ represents the highest energy consumption on a given route between two stops corresponding to the shortest possible running time $\mathrm{T}_{\min }$. Prolongation of running time $T$ is achieved by variants, as may be observed in clarification of particular curves in Figure 3.

Each running time $T>T_{\min }$ corresponds with energy consumption $E<E_{\max }$. Optimal running time was achieved by means of mathematical reasoning, which determines energetically optimal running time as running time, which corresponds with a dot on the curve of a relevant functional relation $\varepsilon(\tau)$, for which the following holds true:

$$
\frac{d \varepsilon}{d \tau}=-1
$$

This means that it is a point where a relative increment of energy consumption will trigger an identical relative shortening of running time, and vice versa. If we connect points on individual curves in Figure 3, for which the above-mentioned mathematical relationship (10) is applicable, we will get a curve, which is marked by dot-and-dashed line and which represents an aggregate of points optimal for running times of all considered cases in the given model conditions.

\section{RESULTS}

If we follow above-mentioned findings with the time reserve $\Delta T_{o p t}$, for which the following is applicable

$$
\Delta T_{o p t}=T_{o p t}-T_{\min } \quad[\mathrm{min}]
$$

then the chart in Figure 3 suggests an optimal curve of time reserve with relevance to the line gradient. In other words, if reserves in running times according to the timetable are higher than those in the mentioned chart, they may lead to energetically unfavorable running times, or else, their sustenance will lead to the uneconomical use of electrical energy after creating a particular transport act. 
The symbol $\mathrm{T}_{\mathrm{JR}}$ in Figure 5 means the running time according to actual timetable.

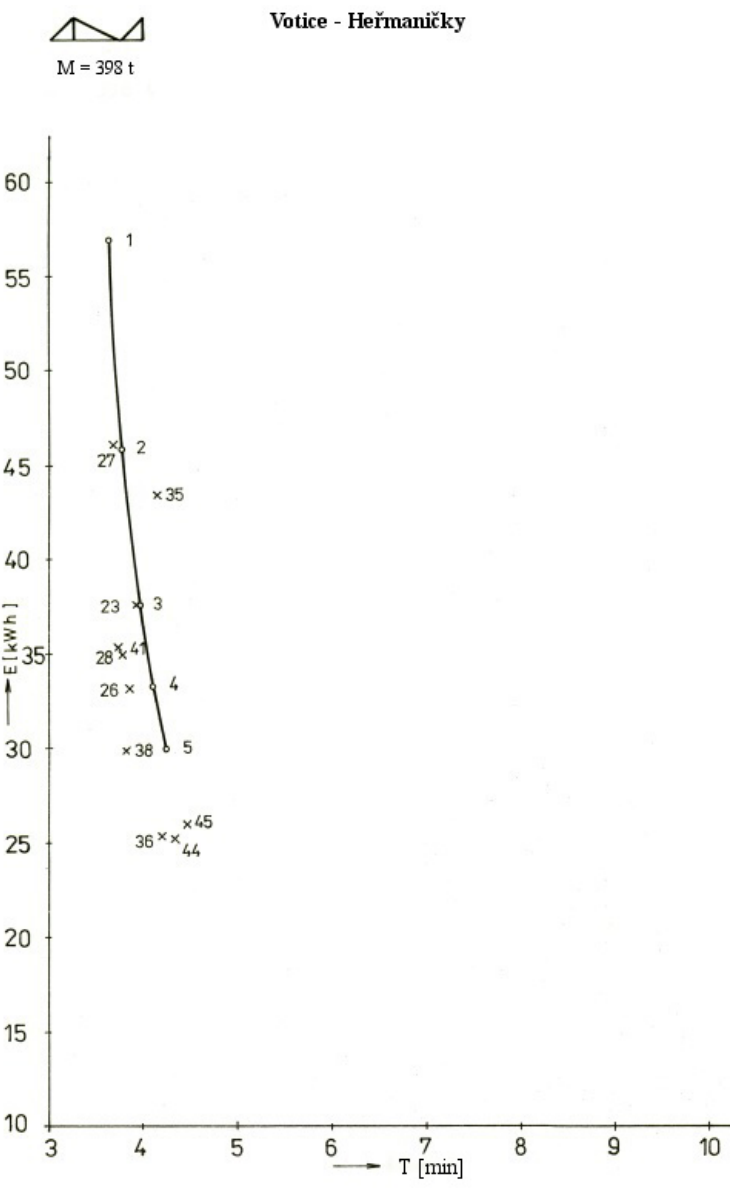

Figure 4: Relationship between energy consumption on the current collector and running time $T$. The displayed calculated values are marked with a circlet and values determined by measurement are marked with a cross

\section{CONCLUSIONS}

Graphic tabular aids for engine drivers, which promote energetically rational train driving, were elaborated upon in the outcomes of the above-mentioned findings. Long-term observations of the influence of running time on energy consumption was examined by variant simulation calculations and by experimental measurements in real train operation. Charts in Figures 3 and 4 present illustrations of calculations and measurements performed during the operational routine. The degree of conformity between calculations and measurements is apparent, the trains in various operational conditions discovered energy savings of between $5-15 \%$. This led to designing an automated navigation aid for locomotive drivers. This device issues guidelines, which respect relevant operational situations during driving. The equipment has been thoroughly tested with favorable result. 


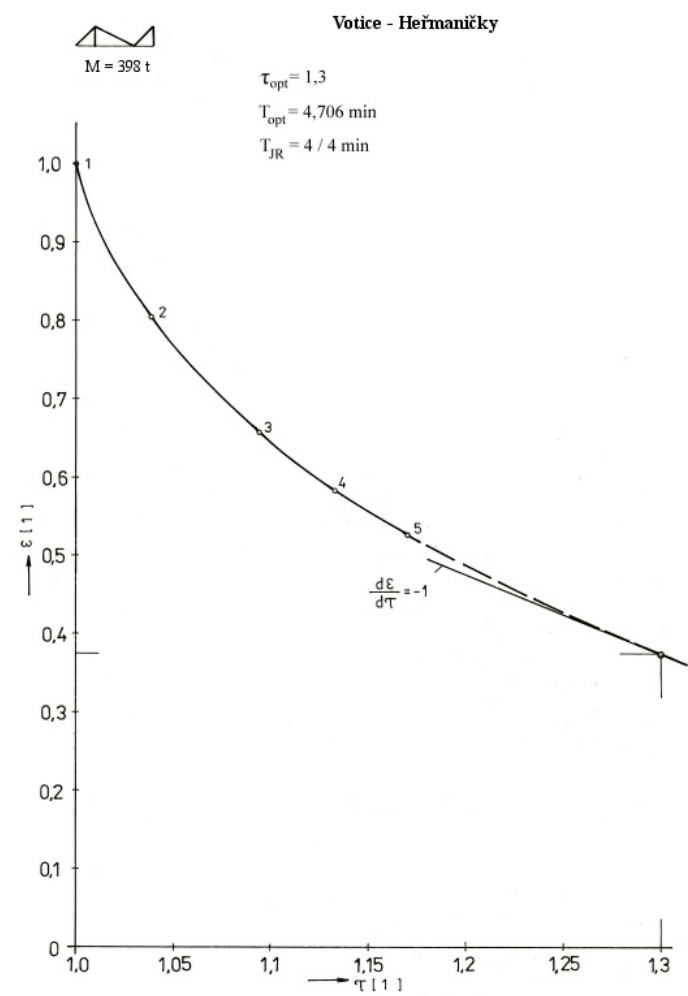

Figure 5: Relations between relative energy consumption relating to the current collector $\varepsilon$ and relative running time $\tau$ based on variant calculations corresponding with the chart are the subject of Figure 4

\section{REFERENCES}

OPAVA: Netradiční řě̌eni energetické hospodárnosti elektrické vozby. In Sborník prací Výzkumného ústavu železničního č. 50. Ed. Praha: Výzkumný ústav železniční, 1994, pp. 59-77. ISSN 0139-7885.

OPAVA: Transportation Energetics as the Object of Scientific Research. In Sborník mezinárodní konference, Praha, ČVUT Fakulta dopravní, duben 2007.

OPAVA: Nový pohled na simulační výpočty velektrické trakci. In 15. mezinárodní symposium EURNEX - Žel 2007: sborník příspěvků symposia, Žilina, květen 2007. Ed. Žilina: 2007. ISBN 978-80-8070-678-4.

OPAVA: Analysis of Traction Energy Consumption. In Industrial Energy and Enviromental Protection in Southeast Europe: sborník př́íspěvků mezinárodní konference. Zlatibor (Srbsko), 24.-27. červen 2008. 